\title{
The Effectiveness of the Principal's Working Group of Public Elementary Schools in Indonesia
}

\author{
Siti Khodijah \\ SD Negeri 5 Lumpatan \\ e-mail: $\underline{\text { sitikh1112@gmail.com }}$ \\ Tri Widayatsih \\ Universitas PGRI Palembang \\ e-mail: triwidayatsih@univpgri-palembang.ac.id \\ Yessi Fitriani \\ Universitas PGRI Palembang \\ e-mail: yessifitriani@univpgri-palembang.ac.id \\ Article History: Received on 23 November 2021, Revised on 10 January 2022 \\ Published on 19 January 2022
}

\begin{abstract}
This study is to determine the actions of the Principal Working Group of SD Negeri in Lumpatan Village, Musi Banyuasin Regency related to planning, organization, implementation, and supervision. The descriptive qualitative approach was used in this study. Techniques for gathering data include observation, interviews, and documentation. The findings indicate that on the planning dimension, the indicators that are less effective are human resources who do not yet have good managerial performance and competence in supporting the preparation of work plans, on the organizational dimension, the indicators for preparing the Principal Working Groups plan and education and training indicators are not running effectively, on the dimension of implementation, what is to be achieved is not running effectively.
\end{abstract}

Keywords: Principal Working Groups, Effective, Elementary School, Indonesia

\section{A. Introduction}

Improving the quality of education, particularly in primary schools, is one of the priorities for improving the quality of human resources. Principal leadership is the most crucial component in every organization because successful leadership makes the organization more effective, while ineffective leadership causes the company to fail to accomplish its vision, purpose, and goals. According to Salusu (2015), a good leader is a builder who views his subordinates as his primary source of strength, has talents in nurturing human interactions, and always strives to maximize the potential of his subordinates. According to Murtiningsih et al (2017), leadership is defined as the activity of influencing, encouraging, inviting, moving, and leading people in the work process to think, conduct, and act in line with relevant norms in order to achieve the goals that have been established. Teachers, according to Siagian (2016), are learning leaders, facilitators, and a hub for learning initiatives. As a result, instructors must always develop themselves autonomously and not rely on the initiative of the administrator. The development of human resources for educators, particularly teacher professional development, is an 
Volume 2 (3) 2021

E-ISSN: 2723-6919 P-ISSN: 2746-0827

endeavor to provide instructors with varied insights, knowledge, and abilities, as well as the confidence to carry out their responsibilities and obligations as professional officers.

Indicators of increased teacher professionalism in learning can be accomplished through empowering teachers' potential and successes. Professionalism is defined as a teacher's ability to act fully, precisely, and effectively. Professional school principals must also have a deep understanding of human nature as the foundation for teachers' mindsets and work patterns, as well as their loyalty to the education profession, in order to develop a meaningful classroom organizational culture and teaching organizational climate that is creative and dynamic, passionate and dialogical, and fun for participants (Rivayanti et al, 2020; Royani and Fitria, 2020).

Educate in line with the requirements of Law No. 20 of 2003, Article 40, Paragraph 2 a) The central government merely establishes competence requirements, fundamental competencies, and indicators of competency accomplishment in the implementation of decentralized education, while the creation of the syllabus of learning materials is submitted to the regions, and then to the principals and instructors. As a result, boosting the quality of teachers' learning, particularly learning to apply the curriculum, may be accomplished through venues such as the Teacher Working Group, Principal Working Groups, and activities that can employ one or two classes in a single elementary school. Teachers may learn from one another and share experiences by participating in this working group, which focuses on contextual learning activities in the classroom. Schools and instructors have the authority or authority to give reinforcement of learning materials based on student mastery as well as regional conditions, while still paying attention to teaching quality and school excellence.

According to the explanation above, the principal is an educational leader who has a significant task and role in developing the quality of education in schools, developing morale, harmonious cooperation, interest in educational development, a pleasant working environment, and professional quality development. The principal's leadership qualities has a big influence on teacher morale. Based on the needs of achieving such a society, efforts to increase educational quality must be made in a holistic manner, encompassing the development of the Indonesian human dimension as a whole, meaning morality, character, character, conduct, knowledge, health, skills, and the arts. The improvement and development of these characteristics leads to the improvement and development of life skills, which are accomplished via the attainment of students' competences to survive, adapt, and prosper in the future. Thus, students build the toughness, independence, and individuality that they need via gradual and continual learning and training. According to Mulyasa (2017), the principal serves as a carrier of command who should be obeyed but is not dictatorial.

According to the researcher, in order to make this happen in the future, Principal Working Groups should have a significant role and function in creating changes in all school components, particularly in school management. To implement a competency-based curriculum and testing system in which the learning orientation shifts from a teaching paradigm to a learning paradigm, these Principal Working Groups position themselves as a group willing to make changes in all fields in general, and education in particular, in order to achieve Principal Helpful and effective Working Groups. The preceding is in accordance with the legal basis for the formation of Principal Working Groups, namely Law Number 20 of 2003 concerning the National Education System, which states that education personnel are required to improve professional abilities in accordance with the demands of scientific and technological 
Volume 2 (3) 2021

E-ISSN: 2723-6919 P-ISSN: 2746-0827

development as well as national development. Furthermore, it is supplemented by Government Regulation Number 38 of 1992 concerning education personnel, chapter XIII article 61 paragraph 1 which states that educational staff can form professional bonds as a forum to improve and or develop careers, abilities, professional authority, dignity, and welfare of education personnel in order to achieve optimal educational goals.

Work activity, according to Siagian (2016), is defined as the completion of work on time. Starting with this, efforts must be made to improve teachers' abilities, particularly in establishing curriculum in educational units, which are their duties and obligations, through a forum known as Principal Working Groups. To make it happen, a pattern of leveraging existing platforms that may stimulate and support school administrators to develop professionalism and be effective in learning via the principal's working group is required. This empowerment activity allows the Principal to provide contributions, thoughts, and performance steps both theoretically and in adequate practice, allowing him to truly become a figure who continues to develop his professional competence, ultimately leading to an improvement in the quality of education in State Elementary Schools in the Sekayu District. Principal Working Groups serve as a platform for teachers who are members of school cluster organizations whose goal is to make teachers more professional in order to improve educational quality.

It is envisaged that by using a professional development system method, teachers would be able to organize, implement, and evaluate learning activities, including curriculum creation at the education unit level. In its implementation, the curriculum as a learning experience tool will position the teacher as a front-line teacher who requires teachers to build themselves and their thoughts, particularly in mastering materials, learning strategies and methods, classroom management, and evaluating learning outcomes. The Principal in a school cluster gathers through this Principal Working Groups forum to discuss things connected to teaching tasks, including establishing the curriculum of the education unit. Based on the explanation of the above viewpoint, it is possible to infer that work effectiveness is a situation characterized by the timely attainment of a set objective by mobilizing human resources via the actions performed.

Primary Working Groups UPTD Education Office at Lumpatan Village, Musi Banyuasin Regency, which comprises of Principals of State Elementary Schools in Lumpatan Village, Musi Banyuasin Regency. This organization's board is directly chosen by its members. The board of directors serves a five-year term and can be nominated and re-elected in the election for the next period. Preparation for the global era characterised by scientific and technological advancement is becoming increasingly competitive. Faced with this paradigm in the sphere of education, human resources who are capable and eager to follow these advancements are required. The principal's job is not just to be a leader and a professional; he or she must also be an educator, motivator, administrator, supervisor, inventor, manager, and have an entrepreneurial spirit. The ability of the Principal of Public Elementary Schools in Lumpatan Village, Musi Banyuasin Regency to fulfill these tasks is still required and should be developed. It is known that Lumpatan Village, Musi Banyuasin Regency has six public elementary schools, six of which are state-owned, and one MIN. The empowerment of Principal Working Groups of the Sekayu District Public Elementary Schools in the Beneficial Program can provide an excellent platform for strengthening the professionalism of the Principal of Public Elementary Schools. 
Volume 2 (3) 2021

E-ISSN: 2723-6919 P-ISSN: 2746-0827

However, according to Suryadi (2014), national education is still experiencing challenges in providing the community's desire for excellent education. School Oversight Working Group, this working group may support schools in developing and executing curricular work programs in their particular schools by carrying out the presence of Principal Working Groups here. Solutions to difficulties encountered during the production of this curricular work plan will be achieved at each meeting or meeting of the Principal Working Groups. They will share information on the things that must be regarded and the crucial elements that each school must consider while developing its curriculum work plan. Facts on the ground reveal that the existence of Principal Working Groups is critical in order to raise the quality of SDN education in the village to at least parity with public schools in the metropolis. However, the issues that have hampered SDN's survival in the hamlet are still experienced on occasion in the field. These issues derive from the education system itself, namely the village's SDN's inability to balance the dynamics of the community's demand for higher quality education with the dynamics of education in general. Some principals have not been able to properly utilize the principal working group that controls the primary of SDN in the village as a principal forum. This occurred due to a lack of understanding and information regarding the value of Principal Working Groups for school principals, as well as sectoral ego being an impediment to Principal Working Groups demonstrating their presence (Suryadi, 2014).

According to the researchers' observations, the problems faced by the working groups include (1) a lack of interest on the part of members in participating in the training provided by the Principal Working Groups; (2) limited facilities and infrastructure that support the Principal Working Groups program; (3) limited funds to provide training or education for members of the Principal Working Groups; and (4) a lack of follow-up on several programs that have been implemented (Interview, 23 June 2021, to the Principal of SDN Lumpatan, MUBA Regency).

It may be stated that the Principal Working Groups of the Sekayu District Elementary School did not make a substantial contribution to strengthening education in schools in the formulation of the curriculum work plan. Various obstacles are currently being faced by school principals or members of Principal Working Groups in their efforts to create an effective curriculum work plan, such as working group management, which needs to be improved in quality in order to optimize the intensification of working group activity development. Insufficient and improperly used operational support funds are not in accordance with the demands of the principal's professional growth. As a result, efforts must be made to rejuvenate the principal's working group so that the activities carried out by the working group or forum may benefit efforts to raise teacher competency. The preceding is predicted to contribute to the creation of a learning culture based on an effective instructional system, with an influence on enhancing learning quality, which will lead to a rise in national education quality. Based on this context, it is critical to undertake study on the Effectiveness of Principals' Activities in Public Elementary Schools.

\section{B. Methods}

This study was carried out at Lumpatan Village, Musi Banyuasin Regency. This study lasted five months, from July to December 2021. In this study, informants were chosen using purposive sampling, which means that the researcher chose the informants based on the idea that the informants could supply the information required by the research in line with the research problems using interview procedures. In this study, there were four informants: one UPT District Education Office Head, two UPT District Education Office Staff, and one State 
Volume 2 (3) 2021

E-ISSN: 2723-6919 P-ISSN: 2746-0827

Elementary School 5 Lumputan. The research technique utilized in this study is qualitative, with the goal of analyzing the Effectiveness of State Elementary School Principals' Working Group Activities in the Preparation of Work Plans in Lumpatan Village, Musi Banyuasin Regency. In this study, data was gathered by observation, interviews, and documentation. Data triangulation was employed as a data validity approach in this study (Sugiyono, 2018; Moleong, 2021; Hashimov, 2015).

\section{Results and Discussion}

The following table shows the findings of a study conducted by researchers based on the indicators contained in each operational definition of the Effectiveness of the Activities of the Principals of State Elementary School 5 Working Groups in the Preparation of Work Plans in the Sekayu Musi Banyuasin District:

Table 1. Dimensions of Effectiveness of Principals Working Group of State Elementary School 5 in Sekayu District MUBA

\begin{tabular}{|l|l|l|}
\hline Dimension & Focus/Indicator & Results \\
\hline Planning & $\begin{array}{l}\text { Human Resources } \\
\text { Finance } \\
\text { Facilities }\end{array}$ & $\begin{array}{l}\text { Not Good } \\
\text { Good } \\
\text { Not Good }\end{array}$ \\
\hline Organizing & $\begin{array}{l}\text { Principal Working Groups Planning } \\
\text { Troubleshooting Discussion } \\
\text { Education and Training }\end{array}$ & $\begin{array}{l}\text { Not Good } \\
\text { Good } \\
\text { Good }\end{array}$ \\
\hline Actuating & $\begin{array}{l}\text { Curriculum Work Plan Improving } \\
\text { Education Quality }\end{array}$ & Baik \\
\hline Controling & $\begin{array}{l}\text { Curriculum Work Plan Improving } \\
\text { Education Quality }\end{array}$ & Baik \\
\hline
\end{tabular}

According to the table above, the research on the Effectiveness of the Working Group Activities of Principals of State Elementary Schools 5 in the Preparation of Work Plans in the Sekayu MUBA Sub-district was not carried out properly. Only the budget indicators are carried out successfully, according to the planning dimension, but the indicators of human resources, facilities, and infrastructure are still carried out ineffectively. This is related to principals' lack of skill and performance in management competence, as well as the presence of principals with diploma educational backgrounds who have experience as rookie principals. Meanwhile, the facilities and infrastructure are still borrowed or hired from outside. They often do not even employ a sound system, which causes people to lose concentration when engaging in events because the speaker's voice is not audible.

There are flaws in the indicators for the formulation of the Principal Working Groups' work plans, which do not focus on the professional growth of school principals, as well as indicators of education and training in Principal Working Groups activities, at the Organizing stage. Despite the fact that the work plan includes an education and training agenda on the competence of school principals, there are still principals who are unable to attend and are less active in participating in Principal Working Groups activities, resulting in less than optimal knowledge, education, and learning (Cayeni et al, 2020).

The implementation dimensions center on the Curriculum Work Plan Improving Education Quality in the context of strengthening principals' competency in participation in Principal 
Volume 2 (3) 2021

E-ISSN: 2723-6919 P-ISSN: 2746-0827

Working Groups. There are numerous ideas that may be used to inspire school principals so that they can continuously increase their competence and carry out their primary responsibilities. It is still not functioning successfully in the Supervision dimension, which is the dimension of attaining the objectives of the Principal Working Groups operations. Only a handful of the principals who took part in the activity demonstrated an improvement in the quality of their kids' education in comparison to the curriculum work plan that had been developed. Other primary schools, on the other hand, have not been properly implemented (Marlina et al, 2020; Marce et al, 2020).

The Minister of National Education's Regulation No. 13 of 2007 on Standards for Principals emphasizes that a school principal must have five minimal competency characteristics, namely personality, management, entrepreneurial, supervisory, and social capabilities. The principal is a teacher who has been assigned extra obligations as a principal, thus he must also have the needed abilities to be a teacher, which include pedagogic, personality, social, and professional competence.

Based on this fact, numerous ways are used to increase the competency of school administrators. Using the Principal Working Groups forum as a vehicle for collective learning is one way for reaching all school principals in a very short period of time. Principals in these forums can exchange information and experiences with one another in order to improve their competence and performance as a group (Fitra, 2013).

Performance Assessment activities are part of the Performance Management Cycle, according to Human Resource Management. As a result, when a teacher is suggested as a principal based on his positive performance evaluation, he must be able to demonstrate it via his administrative competence. Because, despite receiving coaching and training, as well as performance evaluations, school administrators continue to have less meaningful achievement. Because when a previously great teacher was promoted to the position of principal, the teacher's performance generally suffered while he served as principle. This is due to their inability to carry out their managerial responsibilities. The author uses a reference by Kartini et al (2020) and Qosumudin and Bunyamin (2020) the importance of principal leadership in achieving educational success, implying that the progress of a school is dependent on the principal's managerial position (Ulfathmi et al, 2021; Darwansah et al, 2021).

The Primary Working Groups strategy must be prepared using data, information, and field evidence gathered from the Principal Working Groups' principal members. As a result, school principals' competency will be increased by data, knowledge, and proof in the field, as well as through improvement, learning, and coaching in group activities. It is preferable to seek advice and comments from numerous associated components while preparing work preparation activities, such as the local Education Office, the Principal of the Civil Service School, the School Supervisor, and, if feasible, the LPMP widyaiswara institution and lecturers. According to the Ministerial Regulation, education and training can be used to improve the performance and competence of school principals. Education is the process, technique, and method of teaching and learning that aims to transfer information from one person to another in line with set criteria. Meanwhile, training is a teaching and learning process that uses certain tactics and approaches to develop a school principal's talents and job abilities (Cayeni et al, 2020).

The benefits of education and training for school principals include providing the skills and knowledge required by principals, improving principal performance, assisting principals in 
Volume 2 (3) 2021

E-ISSN: 2723-6919 P-ISSN: 2746-0827

dealing with change, career advancement of principals, increasing the amount of remuneration that can be received by the principal, meeting human resource planning needs, and strengthening principal commitment (Mayasari et al, 2021).

According to the findings of the preceding study, the process of working group activities of principals of public elementary schools in the formulation of work plans at Sekayu MUBA has not been carried out properly. This is due to the fact that human resources, namely the principal, lack the capacity and performance of the principle in management competence. As a result, they are less engaged in contributing ideas for Principal Working Group activity. This also has an influence on emotions of inadequacy and a lack of enthusiasm to move forward, resulting in less-than-optimal education and training in Principal Working Groups activities. Worse, school administrators' inability to organize curricular work focused at enhancing quality has a negative impact (Damayanti et al, 2020).

\section{Conclusion}

To ensure that the curriculum work plan developed in the Principal Working Group activities improves the quality of education for elementary school students in Lumpatan MUBA Village, school principals must demonstrate a strong interest, motivation, and loyalty in carrying out and participating in Principal Working Group education and training activities, so that the knowledge and learning gained will contribute significantly to the improvement of school education. Evaluation and supervision should be carried out from the head of the Principal Working Group, SD supervisors, and the education office throughout the implementation of the work plan for the Principal Working Group activities so that activities may be regulated. And it can give inspiration to principals who aren't always present. When developing the work plan for the Principal Working Group activities, it is preferable to solicit advice and opinions from a variety of sources, including the local Education Office, the Principal of the Civil Service School, the School Supervisor, and, if possible, the LPMP widyaiswara institution and lecturers. So that the activities of the Principal Working Group can be more effective in enhancing the principal's professionalism. Principal Working Group financial management is required so that funds may be used effectively to support operational operations, such as the acquisition of buildings and infrastructure for Principal Working Group activities.

\section{E. Acknowledgement}

We thank to the UPT District Education Office Head, UPT District Education Office Staff, and one State Elementary School 5 Lumputan, Rector Universitas PGRI Palembang, and friends of graduate program educational management Universitas PGRI Palembang who have supported us to do this project.

\section{References}

Cayeni, W., Harapan, E., \& Puspita, Y. (2020). Implementasi Kebijakan Kegiatan Kelompok Kerja Guru Pendidikan Agama Islam di Kecamatan Banyuasin I [Implementation of the Policy on the Activities of the Islamic Religious Education Teacher Working Group in Banyuasin District I]. Jurnal Intelektualita: Keislaman, Sosial Dan Sains, 9(1), 129-138. https://doi.org/https://doi.org/10.19109/intelektualita.v9i1.5584 
Volume 2 (3) 2021

E-ISSN: 2723-6919 P-ISSN: 2746-0827

Damayani, T., Arafat, Y., \& Eddy, S. (2020). Pengaruh Kepemimpinan Kepala Sekolah dan Motivasi Kerja terhadap Kinerja Guru [The Influence of Principal Leadership and Work Motivation on Teacher Performance]. Journal of Innovationin Teaching and Instructional Media, 1(1), 46-57. https://doi.org/https://doi.org/10.52690/jitim.v1i1.29

Darwansah, E., Fitria, H., \& Setiawan, A. A. (2021). The Effect of Principal Managerial Competence and School Facilities on Teacher Performance. Journal of Social Work and Science Education, 2(2), 169-180. https://doi.org/10.52690/jswse.v2i2.247

Fitra, R. A. (2013). Pelaksanaan Fungsi Kelompok Kerja Kepala Sekolah Dasar Negeri Kecamatan Koto Tangah Kota Padang [Implementation of the Functions of the Principal Working Group of Public Elementary Schools, Koto Tangah District, Padang City]. Bahana Manajemen Pendidikan, 1(1), 391-399.

Government Regulation Number 38 of 1992

Hashimov, E. (2015). Qualitative Data Analysis: A Methods Sourcebook and The Coding Manual for Qualitative Researchers. Technical Communication Quarterly, 24(1), 109112. https://doi.org/10.1080/10572252.2015.975966

Kartini, K., Ahmad, S., \& Eddy, S. (2020). Pengaruh Gaya Kepemimpinan Kepala Sekolah dan Komunikasi Interpersonal Terhadap Kinerja Guru [The Influence of Principal's Leadership Style and Interpersonal Communication on Teacher Performance]. Journal of Education Research, 1(3), 290-294.

Law Number 20 of 2003

Marce, S., Ahmad, S., \& Eddy, S. (2020). Manajemen Kepemimpinan Kepala Sekolah Sebagai Administrator Dalam Peningkatan Kompetensi Guru [Principal Leadership Management as Administrator in Improving Teacher Competence]. Islamic EducationJurnal, 1((3)), 76-81. https://siducat.org/index.php/dawuh/article/view/138

Marlina, M., Ahmad, S., \& Eddy, S. (2020). Analisis Kinerja Penilik Pendidikan Nonformal di Dinas Pendidikan dan Kebudayaan Kabupaten Musi Banyuasin [Performance Analysis of Non-Formal Education Supervisors at the Education and Culture Office of Musi Banyuasin Regency]. Jurnal Al Qiyam, 1(1), 180-186.

Mayasari, I., Arafat, Y., \& Setiawan, A. A. (2021). The Effect of Principal Leadership and Teacher Performance Toward Student Achievement. Journal of Social Work and Science Education, 2(2), 188-197. https://doi.org/10.52690/jswse.v2i2.249

Minister of National Education's Regulation No. 13 of 2007

Moleong, L. J. (2021). Metodologi Penelitian Kualitatif [Qualitative Research Methodology]. Remaja Rosdakarya.

Mulyasa, E. (2017). Revolusi Mental Dalam Pendidikan Untuk Merevitalisasi Nilai-Nilai Pancasila Dan Menumbuhkembangkan Wawasan Kebangsaan [Mental Revolution in Education to Revitalize Pancasila Values and Develop National Insight]. Prosiding 
Murtiningsih, M., \& Lian, B. (2017). Proses Pengambilan Keputusan Kepala Sekolah Terhadap Peningkatan Kinerja Guru SMP [The Principal's Decision Making Process on Improving the Performance of Middle School Teachers]. JMKSP (Jurnal Manajemen, Kepemimpinan, Dan Supervisi Pendidikan), 2(1), 87-96. https://doi.org/10.31851/jmksp.v2i1.1156

Qomusuddin, I. F., \& Bunyamin, U. (2020). Pengaruh Kepemimpinan Kepala Sekolah dan Kompetensi Guru Terhadap Kinerja Guru [The Influence of Principal Leadership and Teacher Competence on Teacher Performance]. Jurnal Pendidikan Indonesia, 1(2), 6176. https://doi.org/10.36418/japendi.v1i2.3

Rivayanti, Arafat, Y., \& Puspita, Y. (2020). Manajemen Kepemimpinan Kepala Sekolah dalam Pembinaan Profesionalisme Guru [Principal Leadership Management in Teacher Professionalism Development]. Journal of Innovation in Teaching and Instructional Media, 1(1), 10-17.

Royani, I., \& Fitria, H. (2020). Pengaruh Kepemimpinan Kepala PAUD dan Kompetensi Guru terhadap Kinerja Guru [The Influence of PAUD Principal Leadership and Teacher Competence on Teacher Performance]. Journal of Innovation in Teaching and Instructional Media, 1(1), 36-45. https://doi.org/10.52690/jitim.v1i1.28

Salusu, J. (2015). Pengambilan Keputusan Stratejik untuk Organisasi Publik dan Organisasi Nonprofit [Strategic Decision Making for Public Organizations and Nonprofit Organizations]. Grasindo.

Siagian, S. P. (2017). Teori Pengembangan Organisasi [Organizational Development Theory]. In Islam Repository. Bumi Aksara.

Sugiyono. (2018). Metode Penelitian Kuantitatif [Quantitative Research Methods]. Bandung: Alfabeta.

Suryadi, A. (2014). Pendidikan Indonesia Menuju 2025 Outlook: Permasalahan, Tantangan \& Alternatif Kebijakan [Indonesian Education Towards 2025 Outlook: Problems, Challenges and Policy Alternatives]. Bandung: Remaja Rosdakarya.

Ulfathmi, U., Arafat, Y., \& Setiawan, A. A. (2021). The Influence of Principal Leadership and Work Motivation on Teacher Performance. Journal of Social Work and Science Education, 2(2), 160-168. https://doi.org/10.52690/jswse.v2i2.238 